\title{
ANALISIS KOHERENSI SILABI TEMATIK TERPADU SEKOLAH DASAR TERKAIT TEMA BINATANG DAN TUMBUH-TUMBUHAN
}

\author{
Edi Pujo Basuki ${ }^{1}$, Nailul Authar ${ }^{2}$ \\ ${ }^{1}$ Universitas Nahdlatul Ulama Surabaya \\ ${ }^{2}$ Universitas Nahdlatul Ulama Surabaya \\ e-mail: ediayarga@unusa.ac.id
}

\begin{abstract}
Abstract: Title in English Language. The implementation of the Primary School Thematic Curriculum in Indonesia has changed the focus of learning from learning to focus on separate fields of study to shift to themes with a variety of integrated competencies. It is in line with Dewey's opinion that educators need to create classroom activities that follow the principles of continuity and cohesiveness. In thematic learning, content (basic competencies) of relevant fields of study is integrated in thematic learning. The integration of these competencies shows the relevance of themes, sub-themes (topics) and various facts or information. The coherence of the three will strengthen students' understanding. This study aims to analyze the coherence of elementary school thematic syllabi. The focus of the analysis is limited to themes related to animals and plants. The research design is descriptive qualitative. Data sources for integrated thematic syllabi documents Class I, II, and III. Observation sheet data collection instrument. The analytical method is semantic analysis which focuses on the meaning relation of hypernymy and hyponymy. The results of the analysis show that the global coherence of thematic syllabi is close to perfect with ambiguity of about $12 \%$ regarding context relevance and scope. Meanwhile, local coherence reaches $90 \%$ with ambiguity of $10 \%$.
\end{abstract}

Keywords: Integrated Thematic Syllabus for Primary Schools; coherence; Semantic Analysis

\begin{abstract}
Abstrak: Implementasi Kurikulum Tematik Sekolah Dasar di Indonesia telah mengubah fokus pembelajaran dari pembelajaran berfokus pada bidang studi secara terpisah bergeser pada tema dengan beragam kompetensi terpadu. Sejalan dengan pendapat Dewey bahwa pendidik perlu menciptakan kegitan kelas yang mengikuti prinsip prinsip keterlanjutan dan keterpaduan. Dalam pembelajaran tematik, konten (kompetensi dasar) bidang studi yang relevan terintegrasi dalam pembelajaran tematik. Keterpaduan kompetensi tersebut menunjukkan keterkaitan tema, sub-tema (topik) dan beragam fakta atau informasi. Koherensi ketiganya akan memperkuat pemahaman siswa. Penelitian ini bertujuan untuk menganalisis koherensi silabi tematik Sekolah Dasar. Fokus analisis dibatasi pada tema terkait binatang dan tumbuhan. Disain penelitian adalah diskriptif kualitatif. Sumber data dokumen silabi tematik terpadu Kelas I,II, dan III. Instrumen pengumpulan data lembar observasi. Metode analisis adalah Analisis semantik yang fokus pada relasi makna hypernymy dan hyponymy. Hasil analisis menunjukkan koherensi global silabi tematik mendekati sempurna dengan ambiguitas sekitar $12 \%$ terkait relevansi dan skop konteks. Sedangkan koherensi lokal mencapai $90 \%$ dengan ambiguitas $10 \%$.
\end{abstract}

Kata kunci: silabi tematik terpadu sekolah dasar; koherensi; analisis semantik 


\section{PENDAHULUAN}

\section{A. Latar Belakang}

Implementasi Kurikulum Tematik Sekolah Dasar di Indonesia telah mengubah fokus pembelajaran dari pembelajaran berfokus pada bidang studi secara terpisah bergeser menjadi pembelajaran tematik dengan beragam kompetensi terpadu. Sejalan dengan pendapat Dewey bahwa pendidik perlu menciptakan kegiatan kelas yang mengikuti prinsip prinsip keterlanjutan dan keterpaduan . Keterlanjutan menuntut kesinambungan topik topik dalam satu tema. Keterpaduan menutut pengintegrasian beragam pengetahuan atau kompentensi dasar dari beragam bidang studi dalm proses pembelajaran. Karenanya pembelajaran tematik menjadi pilihan tepat dan telah menjadi kebijakan Pemerintah Indonesia.

Dalam pembelajaran tematik, konten konten (kompetensi dasar) bidang studi yang relevan terintegrasi dalam unit unit pembelajaran tematik. Selain itu, keterpaduan kompetensi tersebut juga menunjukkan keterkaitan level tema, sub-tema (topik) dan detil yang berupa beragam fakta atau informasi. Koherensi ketiganya akan memperkuat pemahaman dan daya ingat siswa. Karena itu secara keseluruhan koherensi secara kognitif menjadi sangat penting. Koherensi tema, sub-tema atau topik, serta fakta atau informasi ini adalah fokus masalah yang hendak dikaji.

Penelitian ini adalah studi analisis dokumen Silabus Tematik Terpadu 2016. Fokus studi pada koherensi teks silabus tematik. Metode analisis menggunakan Analisis Semantik dengan batasan kajian koherensi yang menunjukkan hubungan koherensi global dan koherensi lokal serta kaitan antara informasi detil dengan tema dan sub-tema dari perspektif semantik khususnya dari perspektif hyponomy dan hypernomy.

Penelitian ini bertujuan untuk menganalisa koherensi siliabi tematik Sekolah Dasar. Fokus analisis dibatasi pada tema terkait binatang dan tumbuhan. Secara spesifik tujuan penelitian ini adalah: Untuk mengetahui sejauh mana koherensi antara tema, topik, konten bidang studi (fakta / informasi) terkait tema binatang dan tumbuhan dan untuk mengetahui bagaimana bangunan koherensi antara tema, topik, konten bidang studi (fakta atau informasi) terintegrasi dalam kegiatan pembelajaran tematik berdasarkan silabi tematik Sekolah Dasar terkait tema binatang dan tumbuhan.

Urgensi Penelitian ini yaitu mengingat Kurikulum atau Silabus Tematik Terpadu Sekolah Dasar belum pernah dikaji dari perspektif Semantik, penelitian ini akan sangat berarti untuk perbaikan dokumen kurikulum atau Silabus Tematik Terpadu Sekolah Dasar dan pengembangan pembelajaran tematik yang realtif baru ini perlu penyempurnaan lebih dalam dari beragam perspektif, salah satunya adalah perspektif semantik, khususnya koherensi dokumen atau silabus yang akan berdampak secara nasional.

Pada studi semantik terkait koherensi silabus tematik, teori yang relevan untuk analisis koherensi Silabus Tematik Terpadu Sekolah Dasar adalah koherensi teks, teori sense dan sense relation baik hypernomy maupun hyponomy adalah bagian teori yang relevan untuk mengkaji koherensi silabus tematik. Sealin itu kerangka teori koherensi pengetahuan disusun berdasarkan konsep koherensi sematik bangunan van Dijk (2000) dan konstruk pengetahuan bangunan Freeman \& Socoloff (1995) 
Salah satu properti semantik wacana (teks) adalah koherensinya. Menurut Halliday teks itu koheren bila memenuhi dua syarat: konsisten dengan konteks di mana dia dicipta, dan kohesif semua terkoneksi oleh alat sambung (kata sambung).

Menurut van Dijk (1977:96) koherensi wacana atu teks terrepresentasikan dalam dua level: koherensi linear (local coherence) dan koherensi global (global coherence). Koherensi linier merujuk pada relasi koherensi yang menunjukkan hubungan proposisi yang terekpresikan oleh bangunan kalimat dan urutan kalimat (19977:95). Sedangkan koherensi global sifatnya lebih umum yang mencirikan wacana atau teks secara menyeluruh atau frakmen wacana yang lebih luas. Dia menyebutnya struktur makro sematik. Dimana struktur mikro mengikuti dan dibatasi oleh struktur makro atau koherensi global.

Silabus tematik adalah perspektif baru dalam melihat tingkat pengetahuan (tema, topik, fakta / informasi). Konstruk pengetetahuan mengarah pada tiga konstruk yang terpadu: fakta dan informasi, topik dan tema. Menurut Freeman dan Sokoloff (1995), ketiga konstruk itu perannya besar bagi proses pembelajaran anak. Mereka mendifinisikan tema, topik, dan fakta dan informasi beserta kaitannya satu sama lain dengan jelas yaitu pertama, fakta fokus pada informasi dasar yang didifinisikan secara sempit dan merupakan item item yang terpisah, kedua, Topik (sub-tema) memberikan kontek untuk fakta dan informasi dan menyajikan cara untuk mengorganisir potongan potongan informasi yang terpisah kedalam jenis pengalaman yang dikenal oleh mereka yang berada dalam disiplin disiplin tradisional, dan ketiga yaitu tema didifinisikan dalam isu eksistensi yang lebih luas yang memungkinkan peserta didik untuk mengintegrasikan informasi, topik, dan tema dalam rentang utuh pengalaman manusia. Ketiga hal tersebut adalah unsur penting dalam kurikulum tematik.

Analisis semantik pada studi ini adalah pada koherensi. Mekanisme analisis mengikuti konsep koherensi dan sense relation atau hubungan kata yang menunjukkan makna lebih luas dari perspektif hypernomy dan kata yang menunjukkan area makna selevel atau lebih rendah dari perspektif hyponomy.

Sense adalah ekspresi makna inti yang terlepas dari kontek. Dalam studi ini unsur sense relation (hubungan makana) yang digunakan adalah terkait relasi herarki dan relevansi. Kaitan itu dilihat dari perspektif logis terutama entailment (makna implisit logis) dan perspektif herarki terutama hyponymy dan hypernomy.

Entailment adalah inferensi sebagai implikasi logis. Konsep ini digunakan untuk menganalisis kaitan logis. Hyponymy adalah kaitan makna kata dengan makna kata lain antara skupnya lebih luas dan yang lebih sempit atau yang sejajar. Konsep ini digunakan untuk menganalisis koherensi local. Hypernymy adalah kaitan makna lebih antara yang skupnya lebih luas dengan yang lebih sempit. Konsep ini akan digunakan untuk menganalisis koherensi global.

Adapun skema kerangka teori akan ditampilkan dalam bentuk bagan sbb: 


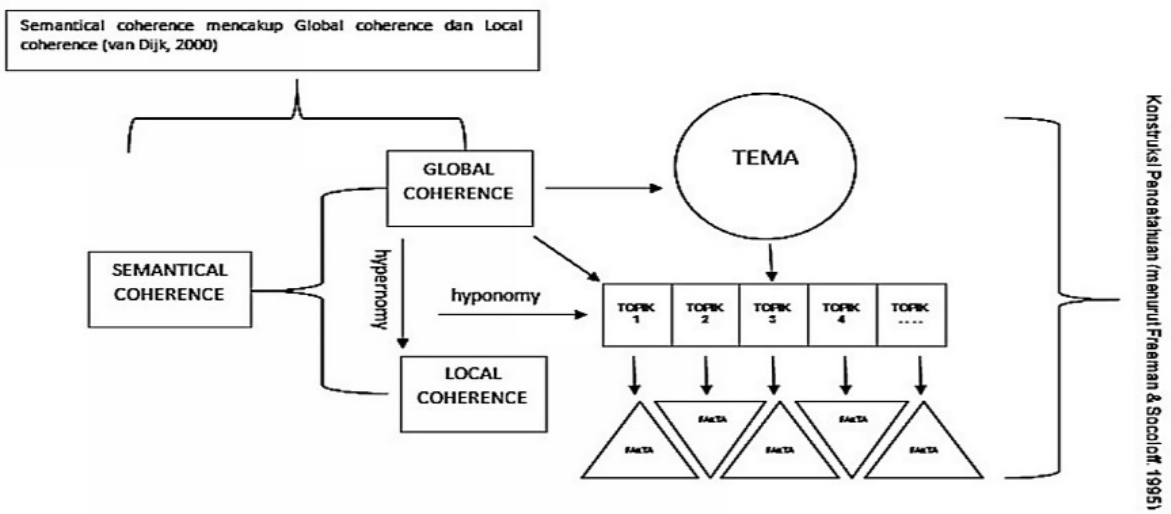

Dokumen dinyatakan koheren bila relasi herarki makna logis tanpa ambiguitas

Gbr 1 Bagan Kerangka Teori Analisis Koherensi Silabi Tematik Terpadu

\section{METODE}

Disain penelitian deskriptif kualitatif. Kerangka penelitian Analisis Semantik. Sumber data dokumen kurikulum / silabi tematik Sekolah Dasar. Fokus analisis semantik pada tema binatang dan tumbuhan untuk mengetahui koherensi, tema, topik, dan fakta dan informasi pada dokumen silabi. Dokumen dibatasi pada Kelas 1,2, dan 3 di mana tema binatang dan tumbuh tumbuhan diturunkan menjadi topik topik pembelajaran. Data penelitihan berupa data kualitatif. Instrument pengumpulan data berupa lembar klasifikasi.

\section{Langkah Penelitian yaitu}

(1)Mengamati dokumen kurikulum dan silabi tematik terpadu. (2)Mengklasifikasikan data pada kolom tema, topik, dan konten atau fakta dan informasi dan catatan hubungan antara ketiganya. (3)Mengklasifikasi konten bidang studi pada masing masing tema dan topik (4)Mencatat inkonsistensi dan irelevansi bila ditemukan.

(5)Menyajikan data (6)Menganalisis koherensi tema, topik, fakta dan informasi. (7)Mendiskusikan sejauh mana koherensi tema, topik, fakta dan informasi yang ada dalam dokumen kurikulum / silabi tematik terpadu

(8)Mendeskripsikan bagaimana koherensi tema, topik dan fakta dan informasi dibangun dalam prosedur pembelajaran. (9)Mendiskripsikan temuan (10)Mendiskripsikan aspek aspek yang perlu peningkatan

Skema Penelitian ini penulis tunjukkan dalam skema berikut ini: 


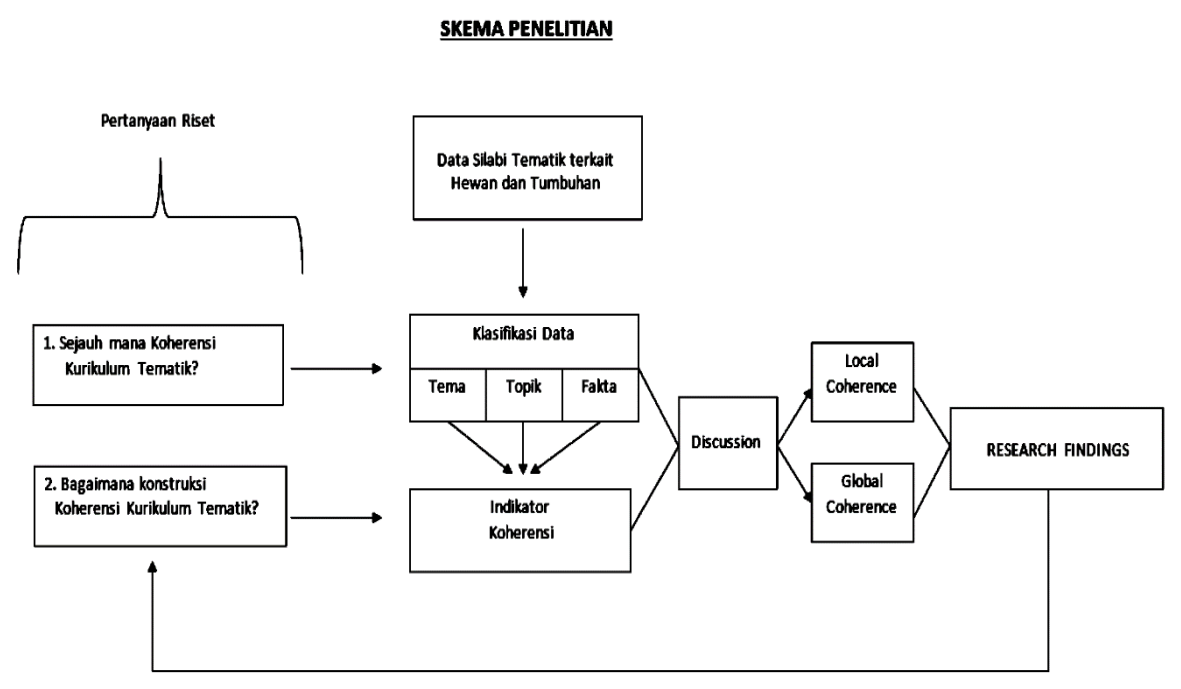

Gambar 2 Skema Alur Penilitian Analisis Koherensi Silabi Tematik Terpadu Sekolah Dasar Terkait Tema Binatang dan Teumbuh Tumbuhan

\section{HASIL}

Setelah menganalisis hasil klasifikasi tema dan topik (sub-tema) dan konten fakta dan / atau informasi yang tersusun dalam Silabi K 13 Tematik Terpadu Sekolah Dasar 2018 diperoleh tingkat koherensi global dan koherensi lokalnya baik. Hasil analisis disajikan dalam tabel jumlah tema dan topik serta konten fakata dan informasi dan kustruk koherensi silabi.

Tabel berikut ini adalah hasil analisis koherensi dokumen silabi.

\begin{tabular}{|c|c|c|c|c|}
\hline $\begin{array}{l}\text { Koherensi } \\
\text { Semantil }\end{array}$ & $\begin{array}{l}\text { Tema } \\
\text { (1) }\end{array}$ & $\begin{array}{l}\text { Topilk } \\
\text { (2) }\end{array}$ & $\begin{array}{l}\text { Konten Falkta } \\
\text { dan info (3) }\end{array}$ & $\begin{array}{l}\text { Tingkat } \\
\text { Koherensi }\end{array}$ \\
\hline $\begin{array}{l}\text { Goherensi } \\
\text { Gobal }\end{array}$ & $4 \tan 2$ & 14 tepils & & $\begin{array}{l}\text { (1)-(2)+hyper } \\
\text { (100\%) } \\
\text { (1)+hypo } \\
\text { (2)+hypo } \\
\text { (2) Amb } \\
(12 \%)\end{array}$ \\
\hline $\begin{array}{l}\text { Koherensi } \\
\text { Lolcal }\end{array}$ & & & 70 unit kenten & $\begin{array}{l}\text { (2)=(3)+hyper } \\
(90 \%) \\
(3)+\text { hypo } \\
(90 \%) \\
(2)=(3) \text { Amb } \\
(10 \%)\end{array}$ \\
\hline
\end{tabular}

Tabel 1 Jumlah Tema, Topik, dan Konten fakta dan / atau informasi

Dari Tabel 1 Model Kurikulum 13 Tematik Terpada 2018 terkait tema Hewan dan Tumbuhan terdiri atas 4 tema, 14 topik, dan 70 unit konten fakta dan informasi dalam 5 
bidang studi (Bahasa, Seni Budaya, Matematika, PPKn, dan Pendidikan Jasmana Olahraga dan Kesehatan. Tabel tersebut menunjukkan koherensi global dan koherensi lokal.

Terkait koherensi global, hasil analisis menunjukkan bahwa koherensi antar tema sangat koheren. Pertama, pada tema pertama menunjukkan aspek dikotomi atau klasifikasi antara benda mati dan benda hidup (benda, hewan dan binatang). Aspek kognitif didahulukan. Kedua, tema kedua fokus pada aspek hubungan manusia dengan hewan dan tumbuhan dibingkai dengan tema Merawat Hewan dan Tumbuhan. Pada tema kedua ini, aspek afektif atau kepedulian terhadap hewan dan tumbuhan menjadi perhatian. Ketiga, Aspek penalaran ilmiah dijadikan fokus agar manusia paham betul untuk bisa merawat dengan baik dan dibingkai dengan tema Pertumbuhan dan Perkembangan Hewan dan Tumbuhan. Aspek Kognitif lebih lanjut menjadi fokus. Yang terakhir adalah aspek afektif dan kognitif disatukan sebagai kepedulian manusia terhadap makluk hidup yang dibingkai dalam tema Menyayangi Hewan dan Tumbuhan. Berdasarkan tabel hasil analisi koherensi antar 4 tema ditunjukkan bahwa tingkat hyponymy terpenuhi. (1)+hypo menunjukkan $100 \%$ koheren.

Sedang terkait koherensi antar tema (1) dan topik (2), Tabel 1 menunjukkan bahwa tingkat koherensi global vertikalnya yang disimbolkan (1)-(2)+hyper bisa dinyatakan sempurna atau antara tema dan topik $100 \%$ koheren. Artinya secara keseluruhan tingkat koherensi global (koherensi antar tema dan tema-topik) baik dari perspektik analisis hypernymy dan hyponym dipenuhi dan sempurna. Cuma ada catatatan terkait nalisis hyponymy antar topik.

Yang perlu dicatat, walau koherensi antar topik secara keseluruhan koheren, namun ada ambiguitas pada dua topik yang diulang dua kali. Di bawah tema ke satu (Benda, Hewan, dan Tumbuhan) ada topik Hewan di Sekitarku dan topik Tumbuhan di Siktarku. Kedua topik yang sama diulang lagi pada kelas II di bawah Tema Merawat Hewan dan Tumbuhan. Agar tidak sama persis mestinya harus ada penekanan aspek pembedanya. Ketidak jelasan ini menimbulkan ambiguitas kontek kedua topik yang diulang tersebut. Dampaknya juga menimbulkan kerancuan koherensi dan relevansi konten pada kedua topik tersebut pada level koherensi lokal. Table menunjukkan tingkat ambiguitas koherensi antar topik mencapai sekitar $15 \%$.

Kemudian terkait koherensi lokal tingkat koherensinya tidak sesempurna koherensi global dokumen silabi tematik terpadu terkait tema hewan dan tumbuhan. Tabel 1 menunjukkan bahwa koherensi antar topik dan konten bidang studi yang disimbulkan dengan (2)-(3)+hyper (90\%) tidak terpenuhi secara sempurna. Tingkat koherensi antar topik dan konten hanya $90 \%$. Tingkat ambiguitasnya $10 \%$.

Ambiguitas itu akibat konten yang tidak relevan dan ketidak jelasan skop kontek. Pada topik Merawat Tumbuhan dan topik Pertumbuhan dan Perkembangan tumbuhan. Persisnya, konten bahasa Indonesia terkait permainan tradisional dan konten Pendidikan Jasmani, Olahraga dan Kesehatan. Topik terkait merawat tumbuhan, kontennya tentang membuat dialog tentang permainan tradisional, dan topik terkait merawat tumbuhan kontennya tentang berlatih gerak dengan permainan tradisional. Selain tidak relevan skornya tidak jelas. 


\section{PEMBAHASAN}

Berdasarkan hasil analisis, konstruk koherensi silabi kurikulum 13 tematik terpadu 2018 terkait tema hewan dan tumbuhan bisa dilihat pada Gambar 3 berikut.

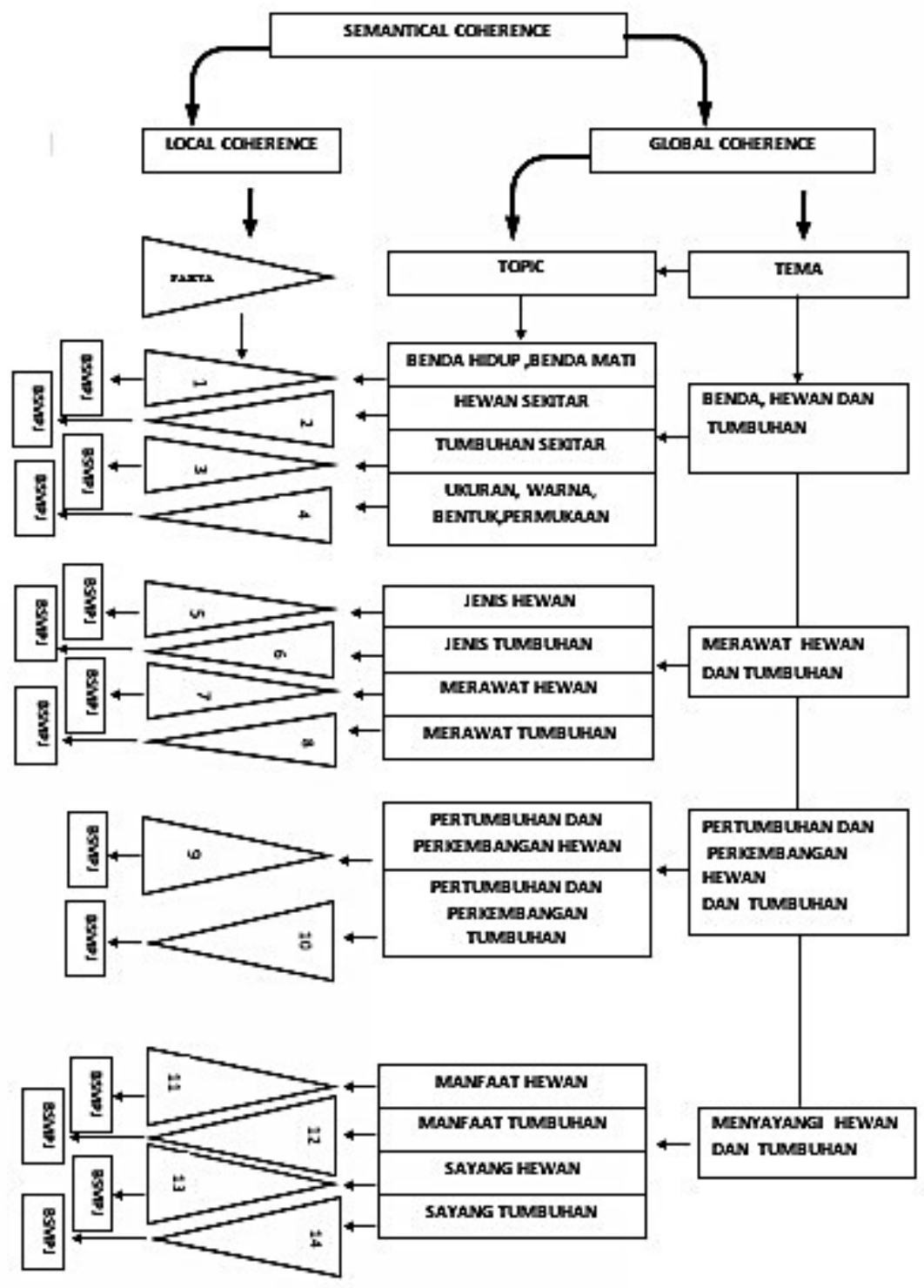

Gambar 3. Kostruk Koherensi Tema, Topik, Konten Silabi Kurikulum 13 Tematik Terpadu 2018 SD / MI terkait Tema Hewan dan Tumbuhan

Keterangan gambar:

- Gambar segitiga adalah konten fakta dan informasi.

- BSMPJ adalah konten bidang studi Bahasa Indonesia (B), Seni Budaya (S), Matematika (M), Pendidikan Pancasila dan Kewarganegaraan (P) dan Pendidikan Jasmani, Olahraga dan Kesehatan. 
Bagan di atas adalah hasil analisis konstruk koherensi dokumen silabi kurikulum 13 tematik terpadu SD terkait tema hewan dan binatang. Berdasarkan hasil analisis koherensi global sempurna, namun ada dua catatan yang perlu diperbaikan untuk perbaikan revisi berikutnya. Pertama terkait topik ke-2 dan ke-3 (Hewan di Sekitarku dan Tumbuhan di Sekitarku) di bawah tema Benda, Hewan, dan Tumbuhan diulang dengan topik yang sama pada topik ke-5 dan topik ke-6 di bawah tema Merawat Hewan dan Tumbuhan. Untuk membedakan aspeknya penulis menambahkan kata jenis hewan dan jenis tumbuhan. Hanya sekedar contoh bahwa tidak ada topik sama persis. Untuk koherensi lebih baik, tentuk diperlukan kajian lebih lanjut.

Singkat kata, hasil analisis koherensi dalam menjawab pertanyaan sejauh mana tingkat koherensi tema, topik, dan konten silabi tematik terpadu menunjukkan bahwa koherensi global silabi hampir sempurna. Dalam perspektif hypernymy koherensi global sempurna, namun dalam perspektif hyponomy menunjukkan ambiguitas $15 \%$ terkait koherensi antar topik (2)(3) dan topik (5)(6). Sedangkan terkait koherensi lokal, hasil analisis menunjukkan koherensi topik-konten dan antar konten dalam satu konteks masing masing 90\% dengan tingkat ambiguitas 10\% terakait revansi dan skop konteks.

Sedangkan bangunan kustruk koherensi secara keseluruhan cukup kuat baik dari perspektif relasi makna hypernymy maupun hyponymy. Hanya perlu dicatat, pada topik (5) dan (6) aspek pembedanya harus jelas sehingga akan semakin koheren hubungan logis topik dan kontennya serta antar konten dalam topik yang sama.

\section{SIMPULAN DAN SARAN}

\section{Simpulan}

Berdasarkan hasil analisis dan pembahasannya bisa disimpulkan bahwa secara keseluruhan koherensi global silabi tematik terpadu sempurna 100\% dari perspektif analisis hypernymy dengam ambiguitas sekitar $12 \%$ dari perpektif analisis hyponymy. Sedangkan koherensi lokalnya bisa disimpulkan tingkat koherensi lokalnya mencapai 90\% dengan tingkat ambiguitas 10\% terkait relevansi konten dan skop konteks.

Berdasarkan hasil analisis konstruk koherensi silabi tematik terpadu secara keseluruhan cukup kuat sebagaimana ditunjukkan pada gambar 3 di atas.

\section{Saran}

Pertama, saran perbaikan dua topik yang sama (topik 1-2 dan topik 5-6) perlu diperjelas aspek pembedanya selanjutnya konten dibawahnya perlu disesuaikan. Kedua, perlu dilakukan analisis semantik dengan fokus yang berbeda dengan harapan secara bertahap kurikulum tepak terpadu SD / Mi akan minimal mendekati sempurna. 


\section{DAFTAR RUJUKAN}

Dewey (1938). Experience and Education. New York: Kalpa Delta Pi.

Freeman dan Sokoloff (1995). Toward a Theory of Thematic Curricula: Contructing New Learning Environment for Teachers and Learners. Education Policy Analysis Archieves Volume 4 Number 14.

Halliday and Hasan (1976). Coherence and Cohesion. London: Longman.

Hurford, Heasly, and Smith (2007). Semantics. New York: Cambrige University Press..

Kementrian Pendidikan dan Kebudayaan (2016) Silabus Sekolah Dasar Tematik Terpadu.

Van Dijk (1980). The Semantics and Pragmatics of Functional Coherence in Discourse in Journal of Pragmatics 4: 233-252.

Van Dijk (1977). Text and Context. London and New York: Longman. 